Mini Review

\title{
Effect of climate change on microbial growth
}

Keywords: microbial growth, microorganisms, photosynthetic algae, cyanobacteria, prochlorococcus, synechococcu

\section{Introduction}

The cover of gases that surrounds the Earth is getting much thicker. These gases are trapping more heat in the atmosphere causing the planet to warm up, which causes global warming. Most specialists now agree that climate change is taking place. This is being demonstrated globally by the melting of the polar ice sheets and locally by the warmer winters we are having, coupled with more extreme weather such as heavy rain and flooding. The Earth is surrounded by a thick layer of gases which keeps the planet warm and allows plants, animals, and microbes to live. These gases work like a cover sheet. Without this covered sheet, the Earth would be $20-30^{\circ} \mathrm{C}$ colder and much less suitable for life. Climate change is happening because there has been an increase in temperature across the world. This is causing the Earth to heat up, which is called global warming. ${ }^{1,2}$

Microorganisms play an important role as either generators or users of these gases in the environment as they are able to recycle and transform the essential elements such as carbon and nitrogen that make up cells. Bacteria and archaea are involved in the 'cycles' of all the essential elements. Photosynthetic algae and cyanobacteria form a major part of the aquatic plankton. They play a key role in the carbon cycle as they carry out photosynthesis and form the basis of food chains in the oceans. Fungi and soil bacteria the decomposers-play a major role in the carbon cycle as they break down organic matter and release carbon dioxide back into the atmosphere.

Prochlorococcus and Synechococcus are single-celled cyanobacteria. They are the smallest yet most abundant photosynthetic microbes in the ocean. They are so small that a hundred of these organisms can fit end-to-end across the width of a human hair and there are around 100million Prochlorococcus cells per liter of seawater. The microbial community was not resistant to warming - it changed - and it wasn't flexible - it didn't recover over time through acclimation to the new environment. The different study implies that species were lost from the community due to change in temperature. ${ }^{3-5}$ The study was not analyzed to test specifically for local extinction events, however, so while it seems like extinctions were likely we cannot know for sure. Admittedly it can be pretty hard to study threats to microbes due to climate change. Different studies are still going on to find out the link between climate change and microbes population and their growth.
Volume 6 Issue 2 - 2018

\author{
Dilip Kumar \\ Assistant Professor, G B Pant University of Agriculture and \\ Technology, India
}

Correspondence: Dilip Kumar, Assistant Professor, G B Pant University of Agriculture and Technology, Uttarakhand, India, Email Jhadilip27@gmail.com

Received: February 14, 2018 | Published: April 23, 2018

\section{Acknowledgements}

None.

\section{Conflict of interest}

The authors declare there is no conflict of interest.

\section{References}

1. Lawrence D, Bell T, Barraclough TG. The effect of immigration on the adaptation of microbial communities to warming. The American Naturalist. 2016;187(2):236-248.

2. Liang Y, Jiang Y, Wang F, et al. Long-term soil transplant simulating climate change with latitude significantly alters microbial temporal turnover. The ISME Journal. 2015;9:2561-257.

3. Youssef NH, Couger MB, McCully AL, et al. Assessing the global phylum-level diversity within the bacterial domain: A review. Journal of Advanced Research. 2015;6(3):269-282.

4. Mariadassou M, Pichon S, Ebert D. Microbial ecosystems are dominated by specialist taxa. Ecology Letters. 2015;18(9):974-982.

5. Blount ZD, Borland CZ, Lenski RE. Historical contingency and the evolution of a key innovation in an experimental population of Escherichia coli. Proceedings of the National Academy of Sciences. 2008;105(23):7899-7906. 